\title{
Market dynamics of harm and labour exploitation
}

\author{
Jonathan Davies ${ }^{1}$
}

\section{Introduction}

During the last twenty years, there has been a significant increase in the attention given to issues associated with 'modern slavery', human trafficking and forced labour (Anderson, 2015; FRA, 2015; Gadd and Broad, 2018). A range of public, political, and academic attention (within and beyond criminology) has led to significant developments of the ways in which these issues are conceptualised and enforced against (GLA, 2015; HM Government, 2015). However, the anti-trafficking framework tends to consist of the so-called '3Ps' - prevention, protection and prosecution, referring to the need to address root causes, improve victim protection, and to hold perpetrators criminally accountable (Ollus, 2015). While this emphasis has arguably improved overall awareness of the issues and led to some policy improvements, it tends to oversimplify the problems by blaming individuals as the key drivers of exploitation (LeBaron et al., 2015). This is a concern because it neglects the role of the state as being responsible for facilitating exploitation through its regulation of labour markets, border controls, immigration policy, and social policy more widely - rather than simply being a neutral or benign actor that 'rescues' victims from exploitation (LeBaron, 2015).

The purpose of this chapter is to move beyond the traditional anti-trafficking agenda, and instead pay greater emphasis to the role of legitimate businesses, supply chains and markets, as well as the way they are regulated, thereby facilitating exploitation and harm. In doing so, it adopts a criminological lens of harm, which asserts that a large number of actions and omissions associated with corporations are neither criminalised nor

\footnotetext{
1 Research Fellow, Faculty of Law, Tel Aviv University, Israel.
} 
prosecuted. From a worker perspective, this lack of accountability does not make the harm they experience any less important. This chapter contains a number of sections in order to elaborate on the role of businesses and markets, along with the harm that can emerge from them. First, an outline of harm in relation to criminology is provided. Second, key issues related to human trafficking are explored. Third, some underlying explanations for harmful labour practices are signposted, including the role of businesses, supply chains, and the regulatory context. It seeks to address the key question of 'how do some supply chains facilitate harmful labour practices?', drawing on supporting examples where appropriate. The intention here is not to provide a full account of these challenges, but to illustrate recent key developments within the topic areas.

\section{Crime and harm in the workplace}

When considering the workplace, workers are subject to a number of vulnerabilities that may result in labour exploitation or harm. While this chapter focuses primarily on workers, a broader range of harms against businesses, employers, consumers, animals, and the environment may emerge from deviant actions within the workplace. These wider concerns are well grounded in previous work on corporate, organisational and white-collar crime, such as food fraud (Lord et al., 2017), toxic oil spills (Slapper and Tombs, 1999), and the Libor scandal (van Erp et al., 2015). The purpose of this section is to examine the notions of crime and harm, especially with regards to actions or omissions that have consequences in the workplace.

The terms 'labour exploitation' and 'harm' are complex and require some unpacking for the purposes of this discussion. While there is no universally accepted definition of labour exploitation, 'severe exploitation' is typically understood as criminalised actions or processes, including human trafficking and forced labour (FRA, 2015) - increasingly referred to as modern slavery. Other forms of non-criminalised exploitation such as underpayment or unfair dismissal may be covered by regulatory or civil law - sometimes referred to as 'labour abuse' or routine exploitation (Davies, 2018; France, 2016). If taking a broader sociological or even a Marxist view, exploitation can be understood as occurring beyond the scope of criminal and civil law - in the absence of formal sanctions (Scott, 2017). 124 
Terms such as 'lawful but awful' and '3D' (dirty, difficult, dangerous) work are used to refer to issues such as long working hours in low-paid work, physical exhaustion, and degrading treatment by employers. These practices are more controversial since they arguably occur in most occupations in some form, and lack any formal legal sanction. Rather than trying to resolve the tension between these competing definitions, this chapter acknowledges the spectrum of exploitation alluded to above, but refers to a broader criminological perspective of 'harm' as a means to frame the discussion.

Like labour exploitation, harm is a problematic concept. While harm is a well-grounded subject in disciplines such as law and philosophy, it has only recently gained significant attention within criminology (Hillyard et al., 2004; Paoli and Greenfield, 2015; Pemberton, 2015). Greenfield and Paoli (2013: 864) define harm as 'breaches of stakeholders' legitimate interests', referring to functional (physical and psychological), material, reputational, and privacy harms. As part of their typology, harm can (i) range from minor, rare, and momentary occurrences to severe, frequent, and long-lasting consequences; (ii) affect individuals, private and public sector entities, as well as the environment (physical and social) (Greenfield and Paoli, 2013).

Alternatively, some critical criminologists assert that criminology is limited when addressing 'harm' that is not state defined, i.e. harm that frequently occurs beyond the scope of criminal justice systems and formal sanctions, such as air pollution and poverty. They argue that 'social harm' or 'zemiology' ' should be a discipline in its own right in order to study a wider range of harms - therefore beyond the confines of criminology (Pemberton, 2015). While non-criminalised responses to certain incidents (e.g. high levels of air pollution, poor health and safety practices) may be intended to minimise the number of new criminal-legal court cases, the social harm perspective intends to make such cases the focal point of analysis, arguing that it is precisely these issues that risk being overlooked by society, despite the role that corporations and states have in facilitating them. For instance, an employer who violates safety standards that results in a workplace death or severe injury may be regarded by employers and

\footnotetext{
2 Zemiology originates from the Greek word 'zēmía', meaning harm.
} 
the wider public as an 'accident' whereby 'lessons need to be learned', rather than a criminal action deserving guilt and punishment.

The purpose of this chapter is not to resolve these tensions between crime and harm - indeed, it is recognised here that such a resolution is highly unlikely regardless of how much attention is paid to them. The definition adopted for the purposes of this chapter is based on Greenfield and Paoli's (2013) work, who as noted above, define harm as breaches of stakeholders' legitimate interests. Stakeholders, according to their definition, may consist of individuals, businesses, other institutions, as well as the physical and social environment (Greenfield and Paoli, 2013). This chapter does not argue for 'abandoning' criminology, albeit it recognises the value of a social harm approach in drawing attention to wrongdoing that frequently occurs.

Having problematised the theoretical notion of harm, it is important to consider how this may be applied to the context of the workplace. In using Greenfield and Paoli's (2013) framework of harm, it is possible to consider harm to individuals, private and public sector entities, as well as the environment (physical and social). Although this chapter does not conduct a systematic harm 'assessment' in line with Greenfield and Paoli's research due to the lack of empirical evidence, harms can be identified from existing research and developments from the harm agenda. Here, harms affecting workers, businesses, the government, and physical environment are discussed. This discussion is certainly not exhaustive, but provides some illustrative examples of how different groups with potentially competing interests can be harmed.

Workers are subject to numerous harms within the workplace, including labour exploitation and forms of 'modern slavery' (discussed further in the next section), health and safety problems, and in extreme cases, death. Tombs and Whyte (2007) assert that the blame for workplace injuries is frequently placed on workers, or presented as unavoidable accidents; whereas in many cases, blame arguably lies with employers and are preventable incidents. The result is that responsibility tends to be pinned on individual workers, rather than being seen as an organisational problem where employers are not ensuring appropriate safety standards. Regulatory bodies, while they tend to build up specific expertise, they may lack the resources and remit to effectively hold businesses accountable for preventing and reacting to workplace injuries - at least in the UK context. For 
instance, the Gangmasters and Labour Abuse Authority (GLAA) can only licence labour providers in the agri-food sector, which excludes other vulnerable sectors such as construction and social care.

An issue that is increasingly on the public agenda is that of sexual harassment in the workplace, with UK estimates suggesting that approximately $40 \%$ of women are affected by unwanted sexual advances while at work (House of Commons, 2018: 7). This can be particularly problematic if the advances are from senior colleagues who have the authority to dismiss or promote workers, or at least make their working lives more difficult for them. The issues of workplace injuries and sexual harassment, then, both suggest forms of physical and psychological harm to individuals in line with Greenfield and Paoli's definition.

\section{Shifts from modern slavery to labour exploitation}

The issues of labour exploitation and 'modern slavery' have received a significant increase in attention during the last 20 years, especially since the UN Convention against Transnational Organised Crime (UNTOC) was adopted. The UNTOC provides a contemporary framework for member states who ratify it to develop their responses to human trafficking. Although there were initiatives and international agreements pre-dating UNTOC, such as the 1926 Slavery Convention, UNTOC represented a shift in emphasis from regarding human trafficking as solely a human rights issue, towards the sphere of transnational organised crime. In recent years, legislation has increased on the issues of human trafficking and 'modern slavery', including the California Transparency in Supply Chains Act of 2012, the UK's Modern Slavery Act 2015, as well as an increasing number of specialist NGOs, charities and other interest groups. However, there are a number of concerns with regards to the 'modern slavery' agenda, both in definitional scope and with the practical issues of implementation and responses.

Modern slavery is commonly accepted as an umbrella term for severe and (usually) criminalised forms of sexual and/or labour exploitation, including human trafficking, forced labour, and domestic servitude (FRA, 2015; GLA, 2015). Most national and supranational governments have integrated these offences into their domestic criminal-legal codes, either as 
stand-alone offences, or as part of broader legislation. However, modern slavery represents just the 'tip of the iceberg' of the exploitation continuum, since not all manifestations experienced in the workplace count as 'slavery', or are even severe enough to be subject to criminal prosecution. There are numerous practices which do not meet such high thresholds, but which could still be considered as exploitative in some form. It is here where definitional (and legal) problems of 'labour exploitation' begin to emerge: labour exploitation has no universally agreed definition, either at the national or international level. While 'modern slavery' also has no internationally agreed definition, its subsets of human trafficking and forced labour (among others) tend to be referred to as severe exploitation (FRA, 2015).

As a means to find some balance between the narrowly defined forms of severe exploitation on the one extreme, and the Marxist 'omnipresence' of exploitation on the other, Scott (2017) has advanced a definition of exploitation that consists of excessive workplace 'control'. While acknowledging that some form of workplace control is necessary and helpful to an extent, he argues that when this becomes excessive, labour exploitation and so harmful consequences result. 'Excessive' control is categorised into three key areas - direct, indirect, and exogenous controls, broadly referring to interpersonal (inter)actions, processes occurring at the organisational level, and dynamics of societal factors respectively (Scott, 2017). These controls are now unpacked further for the sake of clarity.

Direct controls, which could otherwise be loosely referred to as 'micro' factors, refer to individual interactions in the workplace, primarily between employers, managers and employees, that could facilitate harm. For instance, airline cabin crews have reported concerns that their employers have pressured them into working longer hours than stipulated in their contracts without appropriate pay to compensate, as well as charging recruits for their uniforms (Boyle et al., 2017). These practices are also likely to be found in manual, low-wage work such as agriculture, food processing, and construction, due to the fast-moving nature of these industries (EHRC, 2010).

Indirect controls, alternatively viewed as the 'meso' level factors, refer primarily to processes that occur at the organisational level, including workplace culture and decision-making procedures. There is a significant literature that discusses how decisions are made within organisations (e.g. 
Braithwaite, 2017; Gobert, 1994; Passas, 2005), many of which can have adverse consequences on workers. On the one hand, individual managers or employers may pursue rogue actions that are outside the scope of the law - or at the very least, actions that are morally 'dubious'. On the other, structures within an organisation or even the entire industry may shape individual perceptions and actions. Individual employees may consider actions that others in similar positions have taken in order to inform their own decisions (Gobert and Punch, 2003). For example, new businesses in the UK construction sector continue to encourage workers to register as selfemployed, which is a widespread industry practice, despite this being linked to harmful labour practices such as underpayment (FLEX, 2018).

Exogenous or 'macro' controls refer to broader societal factors associated with markets, as well as political, economic, and legal structures, including immigration and welfare regimes. In the case of undocumented migrant workers, for example, it is possible that strict border controls and a lack of opportunities to enter a destination country by legal means resulted in them seeking entry via irregular means. A consequence of this irregularity is that they have no official documentation, which encourages them to remain 'under the radar' by working without a contract, being paid in cash, and potentially relying on others for help with accommodation all of which make workers more vulnerable to exploitation and harm. Other examples of exogenous controls may refer to the dynamics of product and labour supply chains/networks, which are discussed in the next section.

While Scott's (2017) definition of labour exploitation begins to move beyond the confines of the legal system. This is done in the spirit of the social harm agenda discussed in the previous section, which allows criminologists to examine harms that are not part of criminal law state definitions as represented through legal interventions. The risk of pursuing such a loose 'harm' agenda that moves beyond the confines of formal sanctions is that advocates are accused of 'moralising' or at the very least, adopting a less scientific approach (Tappan, 1947). Nevertheless, a harm approach provides the opportunity for criminology to remain relevant in 'grey areas' where demarcations between legal, illegal and criminal actions are not clear-cut, amid accusations that it is limited when addressing 'non-criminal' harms (Scott, 2017). 
As part of this emphasis on the full spectrum of exploitation, there are a number of limitations with the modern slavery agenda which risk overlooking a number of key factors. For instance, it is usually only the most severe, 'newsworthy' and 'outrageous' cases of exploitation that are portrayed in the media, rather than the more mundane, repetitive, and less severe exploitation.

There are a number of caveats to this, since public bodies and the media have recently been paying greater attention to standard business practices which may be harmful to workers, including the 'gig economy' and zero hours contracts, which are both associated with insecure, flexible work (Taylor, 2017).

It is common to identify individuals who are responsible for patterns of criminal and harmful behaviour. In cases of modern slavery and labour exploitation, it may be relatively straightforward to identify individual perpetrators, especially in the more sensationalist cases. As part of this, there is a particular emphasis on 'rescuing' victims from these malicious perpetrators, thereby potentially generating an incomplete depiction of the problem. Instead, the notion of 'victims, villains, and rescuers' is easy to understand and has popular appeal (Anderson, 2015), whereby a malicious perpetrator causes harm to an innocent (female/child) victim; hence, the state intervenes in order to rescue the victim and punish the perpetrator. This is not to deny that there are malicious individuals who deliberately set out to exploit people for the sake of financial gain. However, such discourse has potentially damaging consequences for the way in which exploitation and its resulting harm is addressed. For instance, O'Connell Davidson (2005: 420) asserts that the archetypal victim of human trafficking is depicted as a woman or girl (child) who is being sexually exploited by an individual with links to organised crime. In the 2000s especially, such a discourse on 'ideal victims' limited the attention on other abuses such as labour exploitation and the role of legitimate actors.

There are well-grounded reasons that pinning the blame on a small number of individuals for heinous crimes diverts attention from broader societal factors, including immigration and border controls, supply chains, and the political-legal context (LeBaron, 2015; Tombs and Whyte, 2015). In other words, while the state may indeed 'rescue' some victims from severe exploitation, it is arguably contributing to the underpinning social 
conditions that lead to exploitation in the first place, through its immigration controls and fragmented labour market regulation. For example, the UK has 13 different regulatory bodies that deal with different aspects of labour market enforcement, which is confusing for workers (Citizens Advice, 2017). In severe instances, once victims have been officially recognised as victims of trafficking (through the National Referral Mechanism in the UK, for instance), the level of support provided to victims has a mixed track record (Home Office, 2014), to the extent that 're-trafficking'is a significant concern in the event of limited support for victims. Retrafficking refers to someone who escapes, is 'rescued', or otherwise detaches themselves from the trafficking process, and ends up in similar vulnerable positions that expose them to the same process a second time, frequently due to a lack of support from the destination country or their country of origin (Jobe, 2010). It is on this basis that researchers across disciplines have paid a strong level of attention to the role of businesses, supply chains and their oversight (e.g. Barrientos, 2013; EHRC, 2010; Potter and Hamilton, 2014) in order to develop more nuanced depictions of the problem.

\section{The role of businesses, supply chains and markets}

As noted in the previous section, focusing exclusively on individual perpetrators may be helpful in the most extreme cases of labour exploitation where individuals are more easily identified. However, shifting the focus onto the role of businesses, their supply chains, and the otherwise legitimate markets in which they operate, arguably provide a more comprehensive explanation for how exploitation and harm occurs. Supply chains can be defined as a system of suppliers, manufacturers, distributors, buyers (retailers) and customers, where materials feed forward from suppliers to customers, and demand feeds back from customers and buyers (Stevens, 1989). In the agri-food industry, such an example can be seen with how growers purchase tomato seeds, before, planting, growing, and eventually picking the tomatoes. The products are then packed, transported to wholesalers or buyers, before consumers purchase them from supermarkets, smaller grocers, or restaurants etc. 
However, in the case of food production, Croall (2012) argues that the economic context of the global food system is criminogenic, since it encourages a culture where profits are prioritised to the extent that deviant corporate behaviour is normalised. For instance, the research of Lord et al. (2017) found in the drinks industry that internal market actors played a key role in facilitating the tampering of labels (i.e. 'best before' dates), rather than being an exclusive problem of external criminal actors. Similarly, the 2017 Grenfell Tower incident in London, where 72 people died in a fire that engulfed the building, highlighted serious concerns regarding corporations prioritising profit over appropriate building safety standards (BBC News, 2018). According to Ruhs and Anderson (2010), workers, far from being passive victims, may sometimes benefit from deviant corporate practices by colluding with employers. Their research found that migrant workers who were legally resident in the UK colluded with employers to exceed employment restrictions associated with their immigration status in order to earn more money, whereby the lack of oversight in the supply chain helped to facilitate this (Ruhs and Anderson, 2010).

By focusing on broader market and business factors, rather than just criminality, the issues under consideration begin to move beyond the traditional confines of criminology and the criminal justice system, which integrates well with a harm-based approach in order to more fully understand how and why labour exploitation occurs. This section begins by considering some key issues in relation to increasingly standard business practices, including precarious work and subcontracting, while examining important economic sectors where these processes have resulted in harm, including agriculture, food production, education, healthcare, and hand car washes.

Corporations and organisations more broadly have frequently been identified as hotspots for deviant and criminal activity by critical criminologists (e.g. Box, 1984; Gobert and Punch, 2003; Tombs and Whyte, 2015). According to this body of work, organisations provide the motivation, the opportunity, and the means for deviant behaviour that can harm employees, the interests of the organisation, consumers, the public, as well as the environment. This is frequently conceptualised and applied to case studies within the areas of organised crime, state-corporate crime, white-collar crime, and green criminology (Gray and Hinch, 2018; Paoli, 2014). Incidents ranging from oil spills, faulty car manufacturing, food production, 
consumer fraud, air pollution, and more recently, harm to non-human animals, have all been important focal points in these spheres of interest. For example, the impacts of climate change on farming and sustainable production have recently been a subject of focus for researchers (e.g. White and Yeates, 2018). In terms of labour conditions, there have been important developments, especially since the 1970s, that have shaped increasingly common workplace practices.

Many economic sectors, especially in Europe and North America, have been affected by various developments associated with neoliberalism. Neoliberalism is strongly associated with privatisation of industries, deregulation (or a lack of regulation), flexible working conditions, stricter immigration and welfare regimes (LeBaron, 2015), as well as a stronger emphasis on individual responsibility. Part of this process is sometimes referred to as Fordism and 'post-Fordism' (Melossi, 2003), whereby the former represented an era of mass industrial production, full employment, and stable work. The latter tends to represent post-industrial production that is in decline and fragmented across numerous countries, as well as precarious and flexible employment that does not guarantee a stable income or ability for workers to plan their lives in the long term.

Interlinked with these post-Fordist conditions is the rise of globalisation, where supply chains and networks have significantly expanded and become more complex (Barrientos, 2013). As part of this process, farmers and producers at the beginning of the chain, who are frequently (though not exclusively) in the Global South, have faced increasing price pressure and deterioration of profits due to the buying power of larger, multi-national corporations who buy their products for distribution and sale in the Global North (LeBaron et al., 2018). Such dynamics are particularly apparent in agriculture and food production, whereby farmers have seen a 'race to the bottom' in terms of wages and general working conditions (Scott, 2017) due to the bargaining power of global firms that dominate the industry who increasingly price out smaller scale producers.

While some multi-national corporations have developed strategies to tackle the issue of modern slavery and ethical initiatives (New, 2015), not only have these approaches been criticised as superficial, but large buyers such as retailers may be several steps away from where exploitation and harm occurs at the bottom-end of supply networks, therefore arguably do 
not fully understand the consequences of their decisions. For instance, decisions made at the top-end of supply networks may be made with the best economic intentions in mind for the business and shareholders, without regard to the impact that these decisions can have on workers who are frequently based in other countries and occupy low-wage positions. An example is the garment industry in Bangladesh, where the Rana Plaza collapsed in 2013 due to poor safety standards and a lack of oversight, killing 1,100 people and injuring 2,500 (CIOB, 2018: 8).

Despite some international bodies and movements, including the International Labour Organization (ILO) and the International Trade Union Confederation (ITUC) advocating improved working conditions across global supply chains/networks, these bodies have little formal authority. This remains largely with national states and regulatory frameworks, who have struggled to keep up with global developments in terms of their responses. Simply put, it is highly problematic for national governments to regulate global supply networks by themselves, due to the number of jurisdictions that products may pass through from production to consumer shelves. However, aside from a small number of supranational frameworks, such as the Council of Europe Convention on Trafficking, most states implement their own legislation in order to tackle labour abuse, which can vary widely between the confines of civil and criminal law. These regulatory concerns and forms of oversight are explored further in the next section.

\section{Workplace and industrial relationships}

Alongside the business and supply chain practices identified above, these have been accompanied by a gradual shift from collective organisation and bargaining to individual employment rights/contracts, in part due to the decline of labour movements since the late 1970s (Turner et al., 2014). In the UK context, trade union membership has gradually declined from almost 14 million to little more than 6 million between the late 1970s and 2017 (BEIS, 2018). This has harmful impacts on workers, since they are less able to negotiate better working conditions as with individual employers. Thus, if workers are not part of trade union movements, which potentially serve as a bulwark against exploitative workplace practices, then 
workers are potentially less influential in improving their day-to-day work conditions. Such issues are prevalent in transport/taxi firms, as well as people who work for (food) delivery companies, and construction workers, who are routinely denied full working rights due to their self-employed status (FLEX, 2017).

Third, and partly as a consequence of reduced trade unionisation, the growth of 'atypical' or 'non-standard' employment has increased during the last decade (Hipp et al., 2015). These concepts refer to work that is not full time, permanent, and not accompanied with various employment benefits such as sick pay, holiday pay, and pension plans. Non-standard employment, therefore, consists of flexible, part time, temporary or seasonal work, often with very few or no employment benefits, especially if workers are employed through agencies or other labour market intermediaries. Some workers are even pressured to register as self-employed as a way for firms to avoid paying appropriate levels of tax and/or providing employment benefits such as paid sick leave (FLEX, 2017). Figures suggest that in the UK, this 'precarious' work has increased to affect up to 10 million workers (GMB Union, 2017). Hence, atypical and non-standard work is becoming increasingly typical and standard within labour markets. Has a new proletariat emerged?

While businesses (and governments) may cite the benefits of flexible contracts, including many workers 'choosing' flexible work, and demonstrating that their companies can respond flexibly to ever changing market dynamics, such employment conditions can be associated with exploitation and harm. For example, workers who are employed on flexible contracts can be more easily dismissed than permanent employees, which potentially gives a greater degree of control to businesses, by denying workers rest breaks or toilet breaks, or 'encouraging' them to work harder and faster under the threat of dismissal should they fail to comply (EHRC, 2010). This issue integrates with the notion of labour subcontracting, whereby a business may hire workers from an agency on a temporary basis, in order to meet peaks in demand. Businesses can then easily discard these workers back into the 'reserve labour pool' once the peak of demand falls again, since they are not permanent employees of the business and so do not have to provide full employment benefits. Having said that, such issues are not new - van Duyne and Houtzager (2005: 165) point out that business sectors 
such as construction, garment manufacturing, and horticulture have frequently relied on cheap labour in order to manage the demands of volatile market conditions.

Fourth, there is a heavy reliance on migrant labour in key economic sectors. It should be stressed that, in the author's view, increased migrant labour is not the cause of increased modern slavery or exploitation; nor is exploitation the cause of further migrant labour. Arguably, the post-Fordist conditions that have been building up over recent decades have far more to do with the issue of labour exploitation and harm than increased migration flows to destination countries, since these conditions affect all workers, especially those who occupy low-wage positions, not just migrants. Therefore, while the issues of migration and labour exploitation are certainly connected and overlap: one does not cause the other.

\section{Regulatory oversight of labour exploitation and harm}

The question of how to tackle labour exploitation and modern slavery has long been a focal point for researchers, both in national and international contexts (LeBaron et al., 2018; Ollus, 2016). Arguably, single intervention will serve as a 'silver bullet' for exploitative practices; this point seems to be especially valid when addressing severe exploitation and labour abuse (France, 2016). Traditionally, there has been a focus on the 'three Ps', referring to prevention, protection and prosecution, which has had mixed results in terms of addressing root causes, victim protection, and offender prosecution respectively. However, these approaches potentially neglect the role of the state and businesses in facilitating exploitation, through (lack of) regulation of markets and business activities. A discourse of 'rescuers, victims and villains' is the result, which was alluded to above as a critique of the anti-trafficking framework. More recently, however, there has been a greater emphasis on alternative forms of oversight, including state regulation, labour inspections/audits, corporate social responsibility, and labour or trade union movements (Scott, 2017; Tombs and Whyte, 2015). While all these issues cannot be covered with the rigour that they deserve here, a discussion of some key issues in terms of regulatory oversight is presented, with a particular focus on the UK context. 
Within and beyond criminology, there is an assumption that regulation and enforcement against deviant behaviour is difficult to 'do well' (Braithwaite, 2008: 62) due to the number of actors and processes that may be involved in given situations. Ayres and Braithwaite (1992: 35) develop a regulatory 'pyramid' in order to conceptualise different responses to criminal activity, especially in relation to businesses.

At the bottom-end of this pyramid, oversight is based on persuasion and negotiation between regulators and businesses, whereby responses gradually get harsher towards the top-end, progressing from warning letters to civil and criminal law intervention. As Almond and van Erp (2018) argue, it is here that interdisciplinary problems are apparent, because criminology tends to emphasise only the 'top-end' of this regulatory pyramid by focusing on criminal law responses to deviance. On the other extreme, regulation tends to focus on the 'bottom-end' by emphasising meditation rather than punishment as the most constructive way forward. These points concerning the regulatory pyramid relate to harmful labour practices, since criminology tends to focus on 'top-down' criminal law and criminal justice system responses to the most severe harm, while potentially overlooking other forms of 'bottom-up' intervention. These tensions are outlined for the rest of this section.

Police and criminal law involvement are clearly necessary, and sometimes lacking, in many cases of exploitation. Even in relatively well-publicised cases that have identifiable individual perpetrators, this does not guarantee a criminal prosecution or conviction. A useful example in the UK is the DJ Houghton case, where a group of Lithuanian workers were transported to the UK and subject to severe forms of exploitation while working across different UK farms, including substandard accommodation, sleep deprivation, and withholding of payment (The Guardian, 2016). Although there was an initial police investigation into the employers (the Houghtons) and their associates, no criminal charges materialised, which resulted in the workers eventually securing financial redress through the civil courts, based on breaches of employment law. While the reason for the lack of a criminal charge was not explicit, there are suggestions that there was a lack of evidence to proceed, especially since one of the suspects could not be traced (The Guardian, 2016). In many respects his case gets to the heart of debate in terms of whether such events should be considered 
as 'crimes' in the absence of criminal convictions (Sutherland, 1941; Tappan, 1947). While it could be argued that the Lithuanian workers in this case were subject to exploitation and suffered harmful consequences, labelling the business owners as 'criminals' or their actions as 'criminal' is dubious, at least in legal terms.

Given the severity of the DJ Houghton case, this suggests that even where individual perpetrators seem to have a strong role in facilitating exploitation, securing a criminal conviction is far from a foregone conclusion. Proving intent and linking the accused to specific actions beyond reasonable doubt has long been an issue within the sphere of enforcing against corporate and white-collar crime (Gobert and Punch, 2003). Therefore, when considering the spectrum of exploitation and the 'grey areas' in between decent work and severe exploitation, involvement from the criminal justice system is even less likely (France, 2016). Instead, responses from civil law or specialist regulatory bodies may take a more prominent role, assuming that concerns of exploitation are reported in the first place. It is therefore possible that police and prosecution authorities are reluctant to press charges, especially if they lack the financial resources and legal expertise that are available to larger corporations.

Regulatory agencies are usually quasi-governmental bodies that have the authority and, especially over time, develop an area of specialism in order to investigate and potentially prosecute deviant behaviour within organisations and businesses. Given the problems associated with achieving criminal prosecutions, primarily around high thresholds of evidence and proving guilt beyond reasonable doubt, regulatory sanctions or investigations could be seen as an alternative, albeit less severe, form of accountability. However, such regulatory bodies may lack resources and 'teeth' in order to hold businesses accountable for harmful actions or omissions (Balch, 2012). This criticism is broadly directed at states who provide the remit and funding to these regulatory bodies, rather than taking care of the quality of work that such bodies do (although the former inevitably influences the latter to some extent).

Beyond the UK context, other countries present a mixed picture with regards to labour market enforcement. According to International Labour Organisation (ILO) recommendations, developed market economies (i.e. developed countries) should contain one labour inspector per 10.000 workers (Weil, 2008: 351). However, many European countries fall short of this 
standard, with the Netherlands and Poland having 0,5 and 0,8 inspectors per 10.000 workers respectively (FLEX, 2017: 24). Norway, in contrast, has 1,3 inspectors per 10.000 workers, which suggests significantly differing approaches towards labour market enforcement - although there are EU proposals to introduce a European Labour Authority in order to replace or reorganise existing regulatory structures (Kiss, 2018). These issues of inspection are problematic to examine in developing countries, some of which do not keep data on labour inspections or regulatory issues more widely (ILO, 2019).

Some countries have a more fragmented regulatory picture than others. The UK, for instance, does not have a single authority or 'labour inspectorate' that is responsible for regulating against exploitation. Instead, a number of fragmented organisations adopt specific roles, some of which may seem to overlap. The UK's Gangmasters and Labour Abuse Authority (GLAA) regulate labour market intermediaries, traditionally in the agricultural and food industries. The Employment Agency Standards Inspectorate (EASI) oversees employment agencies. In addition, the National Minimum Wage (NMW) team within HM Revenue \& Customs oversee financial issues related to contracts, such as tax payments and National Insurance contributions. There have been some efforts to reconcile these numerous agencies, each of which have different priorities and functions, by developing a common strategy, as seen with the Director of Labour Market Enforcement (HM Government, 2018), who works closely with the GLAA, EASI, and the NMW team. Such a fragmented regulatory context therefore arguably has advantages and disadvantages, through the specialism gained from focusing on a limited number of areas, but at the expense of a unitary authority with a single set of goals.

Other countries have a less fragmented regulatory regime. Finland, for instance, has the Occupational Safety and Health Administration (OSHA), which is the main authority responsible for monitoring work conditions, as well as health and safety (EU-OSHA, 2019). Therefore, countries that contain a national unitary 'labour inspectorate' may find it easier to develop labour market enforcement strategies, rather than having multiple organisations who each have responsibility either for particular stages of labour use (e.g. recruitment), or for particular sectors (e.g. agri-food).

Given the limits of criminal law and state regulation, the notion of corporate social responsibility (CSR) as a form of 'self-regulation' has 
emerged as an alternative to the traditional binary 'regulator-regulated' relationship. Since organisations are in a prime position to facilitate but also resolve harmful workplace practices, there is a question of to what extent they should be permitted to regulate themselves, and what consequences this has on accountability when harm occurs. However, as is well discussed in other literature (New, 2015; Tombs and Whyte, 2015), the key counterargument to CSR is that businesses will tend to prioritise profit over ethical social practices if they are unable to do both. Given that businesses are legally obligated to maximise profits for their shareholders (Fauset, 2006), this generates significant tension - and from a harm perspective, the material interests of shareholders could be harmed if the business chooses to pursue a more expensive social-ethics programme. However, the issue of labour exploitation is increasingly becoming a high-profile issue across many countries and sectors, which means that businesses risk significant reputational damage (and even criminal charges) if they are seen to neglect responsible practices in their supply chains (CIOB, 2018: 6). This is by no means a fool-proof protection, but represents one example of the important role that businesses have in addressing exploitation in their supply chains.

With the development of modern slavery and labour exploitation, and the role that businesses can play in facilitating these practices, a large number of businesses have been keen to emphasise the role that they can have in preventing such practices. Most large companies have some form of labour ethics statements that are publicly available, and more recently in the UK, now publish an annual 'transparency in supply chains' document, in line with the requirements of the Modern Slavery Act 2015. This annual publication sets out the measures businesses have taken to identify 'slavery' in their supply chains, and what they are doing to resolve the problem. However, such legislation applies only to larger businesses whose annual turnover exceeds $£ 36$ million which means that smaller companies are excluded from this remit, even though significant exploitation may occur in these smaller companies. In addition, the legislation focuses exclusively on severe forms of exploitation, including human trafficking and forced labour, while neglecting 'less severe' abuses that fall into the grey area between 'decent work' and violations of criminal-legal codes.

Aside from CSR, there are numerous labour movements and workers' rights advocates groups who aim to encourage workers to be more proactive in challenging workplace conditions through mutual support. As noted 140 
in the previous section, trade union membership has been in decline for some time (BEIS, 2018), and the efficacy of unions in the workplace has been questioned (Potter and Hamilton, 2014). The likelihood of increasing union membership in the context of flexible work practices and transient working populations remains a significant uncertainty in this area. However, the number of charities and similar groups in the UK has expanded in recent years - many of them adopt the 'anti-trafficking' agenda and tend to focus on improving victim's rights and protection. These 'bottom-up' approaches towards improving workplace conditions are fragmented, localised, and focus on particular groups, but in the long term, such community-based responses may be constructive ways forward as part of a broader package involving stronger state regulation in order to oversee organisations.

\section{Conclusion}

This chapter has argued that scrutiny of workplace and supply chain contexts that place workers in vulnerable positions result in a wide range of harmful practices. As Anderson (2010:313) notes, it is important to understand such practices not just as a product of rogue employers, but also of the markets in which they operate. This begins to move away from discussing harm as a problem of individuals to one of businesses, supply chains, markets, and the political-legal contexts in which they operate (Scott, 2017). In order to make such a move, the value of a harm approach is a helpful lens through which to view harmful practices that are neither criminalised nor prosecuted, since numerous harms occur that are hidden within organisations or market relationships. While labelling all these practices as criminal is problematic, there are grounds to assert that they can be harmful to workers and wider society.

Through this lens of harm, it is critical to focus on the full spectrum of labour exploitation, rather than the most severe forms usually categorised as human trafficking, forced labour, and modern slavery (Davies, 2018; France, 2016). More subtle cases and 'grey areas' that fall in between the notions of 'decent work' and severe exploitation are neglected, yet these arguably merit attention, especially if working conditions deteriorate and 
encourage further exploitation to occur. Part of this process involves shifting attention from rogue employers and human 'traffickers' towards a more rigorous understanding of how decisions are made and overseen in contemporary industries.

In some cases, decisions made within businesses may not be intended to cause exploitation or harm to others; instead, they are likely doing what they think is right for their business within the context of competitive environments. However, decisions to subcontract labour or to use flexible employment contracts frequently have unintended consequences, such as confusion for workers whom to report concerns to. Workers who are easily hired and fired tend to be less willing or able to speak up against unfair treatment. More complex supply chains that extend over numerous countries may also make oversight and regulation problematic. Where there is oversight, there are contradictions and limitations associated with topdown responses such as criminal law, as well as bottom-up responses including trade union and labour movements.

Regarding future impacts in the European context especially, estimating the full impacts of Brexit would be highly speculative at this stage, and may not be known for a number of years - signposting these issues may serve as a springboard for further work in future. In particular, concerns around migrant workers' rights, work shortages in migrant dependent sectors such as agriculture, and labour market enforcement, are all subject to ongoing debate (France, 2017). However, if EU-wide enforcement bodies such as the European Labour Authority come into existence, aligning the regulatory systems of different countries may prove challenging, especially given significant approaches towards labour inspection.

These issues all point to a large amount of complexity with regards to the features, organisation and control of harmful labour exploitation. There are a number of disciplines that examine these issues in the context of local, national and global supply chains. However, criminology is perhaps 'guilty' of overly focusing on state based and criminal justice system interventions, while neglecting a broader range of harms that occur within and beyond the workplace. Although this chapter does not advocate 'abandoning' criminology in favour of a social harm discipline, it is clear that a more rigorous assessment of supply chains and business practices within the dominant capitalist system would provide advantages to the discipline 
in terms of broadening its approach and developing contemporary solutions.

\section{References}

Almond, P., and J. van Erp, Regulation and governance versus criminology: disciplinary divides, intersections, and opportunities. Regulation \& Governance, 2018. Epub ahead of print: doi:10.1111/rego.12202.

Alvesalo, A. and D. Whyte, Eyes wide shut: the police investigation of safety crimes. Crime, Law and Social Change, 2007, no. 48(1-2), 5772.

Anderson, B., Migrant domestic workers: good workers, poor slaves, new connections. Social Politics, 2015, no. 22(4), 636-652.

Anderson, B., Migration, immigration controls and the fashioning of precarious workers. Work, Employment and Society, 2010, no. 24(2), 300317.

Ayres, I. and J. Braithwaite, Responsive regulation: transcending the deregulation debate. New York, Oxford University Press, 1992.

Balch, A., regulation and enforcement to tackle forced labour in the UK: a systematic response? York, Joseph Rowntree Foundation, 2012.

Barrientos, S., 'Labour chains': analysing the role of labour contractors in global production networks. The Journal of Development Studies, 2013, no. 49(8), 1058-1071.

BBC News, How the tragedy unfolded at Grenfell Tower [online] available from $<$ https://www.bbc.com/news/uk-england-london-40272168> $\left[28^{\text {th }}\right.$ January, 2019], 2018.

BEIS, Trade Union Membership 2017. Statistical Bulletin. London, Department for Business, Energy \& Industrial Strategy, 2018.

Box, S., Power, crime, and mystification. London, Routledge, 1984.

Boyle, S., G. Keogh, and P. Bentley, How Ryanair cabin crew work five extra hours a day for no pay [online] available from $<$ https://www.dailymail.co.uk/news/article-5188899/ [25 January 2019], 2017.

Braithwaite, J., Regulatory capitalism. How it works, ideas for making it work better. Cheltenham, Edward Elgar Publishing Limited, 2008. 
Braithwaite, V., Closing the gap between regulation and the community. In Regulatory Theory: Foundations and Applications. In P. Drahos (ed.). Acton, ANU Press, pp.25-42, 2017.

CIOB, Building a fairer system: tackling modern slavery in construction supply chains. Bracknell: CIOB, 2018.

Citizens Advice, Employment rights are only as strong as your ability to enforce them [online] available from https://wearecitizensadvice.org.uk/ $28^{\text {th }}$ January 2019], 2017.

Davies, J., From severe to routine labour exploitation: the case of migrant workers in the UK food industry. Criminology \& Criminal Justice, 2018, Epub ahead of print, 10 March 2018. DOI: 10.1177/.

De Giorgi, A., Immigration control, post-fordism, and less eligibility. Punishment \& Society, 2010, no. 12(2), 147-167.

Drahos, P. and M. Krygier, Regulation, institutions and networks. In Regulatory Theory: Foundations and Applications. P. Drahos (ed.) Acton, ANU Press, pp.1-22, 2017.

EHRC, Inquiry into recruitment in the meat and poultry processing sector: report of the findings and recommendations. London, Equality and $\mathrm{Hu}-$ man Rights Commission, 2010.

EU-OSHA, Finland [online] available from $<$ https://osha.europa.eu/en/about-eu-osha/national-focal-points/finland $>$ [28 $8^{\text {th }}$ January 2019], 2019.

Fauset, C., What's wrong with corporate social responsibility? Oxford: Corporate Watch, 2006.

Fisse, B., and J. Braithwaite, The allocation of responsibility for corporate crime: individualism, collectivism and accountability. Sydney Law Review, 1988, 11(3), 468-513.

FLEX, Shaky foundations: labour exploitation in London's construction sector. London: FLEX, 2018.

FLEX, Risky business: tackling exploitation in the UK labour market. London: FLEX, 2017.

FRA, Severe labour exploitation. Vienna, European Union Agency for Fundamental Rights, 2015.

France, B., Lost in transition: Brexit \& labour exploitation. London, Labour Exploitation Advisory Group, 2017.

France, B., Labour compliance to exploitation and the abuses in-between. London, Labour Exploitation Advisory Group, 2016. 
Gadd, D. and R. Broad, Troubling recognitions in British responses to modern slavery. British Journal of Criminology, 2018, 58(6), 14401461.

GLA, Labour exploitation: spotting the signs. Nottingham, Gangmasters Licensing Authority, 2015.

GMB Union, Up to 10 million insecure workers [online] available from www.gmb.org.uk/newsroom/millions-insecure-work. Accessed 22 June 2017.

Gobert, J., Corporate criminality: four modes of fault'. Legal Studies, 1994, no. 14(3), 393-410.

Gobert, J. and M. Punch, Rethinking corporate crime. Cambridge, Cambridge University Press, 2003.

Greenfield, V.A., and L. Paoli, A framework to assess the harms of crimes. British Journal of Criminology, 2013, no. 53(5): 864-885.

Hillyard, P., and S. Tombs, From "crime" to social harm? Crime, Law and Social Change, 2007, no. 48(1), 9-25.

Hillyard, P., C. Pantazis, S. Tombs and G. Gordon (eds.), Beyond Criminology: Taking Harm Seriously. London, Pluto Press , 2004.

Hipp, L., J. Bernhardt, and J. Allmendinger, Institutions and the prevalence of nonstandard employment. Socio-Economic Review, 2015, no. 13(2), 351-377.

HM Government, Transparency in supply chains. London, HM Government, 2015.

Home Office, Review of the National Referral Mechanism for victims of human trafficking. London: Home Office, 2014.

House of Commons, Sexual harassment in the workplace. House of Commons, Women and Equalities Committee, London, 2018.

ILO, Figures and statistics on labour inspection systems [online] available from www.ilo.org/labadmin/info/WCMS_141079/lang--en/index.htm. 28 January 2019.

Jobe, A., The causes and consequences of re-trafficking: evidence from the IOM Human Trafficking Database. Geneva: IOM, 2010.

Kiss, M., European Labour Authority. Brussels: European Parliament, 2018.

LeBaron, G., N. Howard, C. Thibos and P. Kyritsis, Confronting root causes: forced labour in global supply chains. Sheffield, Sheffield Political Economy Research Institute, 2018. 
LeBaron, G., Unfree labour beyond binaries: insecurity, social hierarchy and labour market restructuring. International Feminist Journal of Politics, 2015, no. 17 (1), 1-19.

Lloyd, A., The harms of work: an ultra-realist account of the service economy. Bristol, Bristol University Press, 2018.

Lord, N., C.F. Elizondo and J. Spencer, The dynamics of food fraud: the interactions between criminal opportunity and market (dys)functionality in legitimate business. Criminology and Criminal Justice, 2017, no. 17(5), 605-623.

Melossi, D., 'In a peaceful life': migration and the crime of modernity in Europe/Italy'. Punishment \& Society, 2003, no. 5(4), 371-397.

New, S., Modern Slavery and the supply chain: the limits of corporate social responsibility? Supply Chain Management, 2015, no. 20(6), 697707.

O'Connell Davidson, J. Children in the Global Sex Trade. Cambridge: Polity, 2005.

Ollus, N., Forced flexibility and exploitation: experiences of migrant workers in the cleaning industry. Nordic Journal of Working Life Studies, 2016, no. 6(1), 25-45.

Paoli, L. (ed.), The Oxford Handbook of Organized Crime. Oxford, Oxford University Press, 2014.

Paoli, L. and V.A. Greenfield, Starting from the end: a plea for focusing on the consequences of crime. European Journal of Crime, Criminal Law and Criminal Justice, 2015, no. 23(2), 87-100.

Passas, N., Lawful but awful: 'legal corporate crimes'. The Journal of Socio-Economics, 2005, no. 34, 771-786.

Pemberton, S., Harmful societies: understanding social harm. Bristol: Policy Press, 2015.

Potter, M., and J. Hamilton, Picking on vulnerable migrants: precarity and the mushroom industry in Northern Ireland. Work, Employment and Society, 2014, no. 28(3), 390-406.

Ruhs M. and B. Anderson, (2010), 'Semi-compliance and illegality in migrant labour markets: an analysis of migrants, employers and the state in the UK'. Population, Space and Place 16(3): 195-211, 2010.

Scott, S., Labour exploitation and work-based harm. Bristol, Policy Press, 2017.

Slapper, G. and S. Tombs, Corporate crime. Essex: Pearson, 1999. 
Snider, L. and S. Bittle, The challenges of regulating powerful economic actors. In European Developments in Corporate Criminal Liability. Ed. J. Gobert and A. Pascal, Abingdon, Routledge, 53-69, 2014.

Stevens, G.C., Integrating the supply chain. International Journal of Physical Distribution \& Materials Management 19(8): 3-8, 1989.

Sutherland, E.H., Crime and business. Annals of the American Academy of Political and Social Science, 1941, no. 217(5), 112-118.

Sutherland, E.H., White-collar criminality. American Sociological Review, 1940, no. 5(1), 1-12.

Tappan, P.W., Who is the criminal?. American Sociological Review, 1947, no. $12(1), 96-102$.

Taylor, M., Good work: the Taylor review of modern working practices. London, HM Government, 2017.

Thiemann, I. (2016), Villains and victims, but no workers: why a prosecution-focussed approach to human trafficking fails trafficked persons. Anti-Trafficking Review, no. 6, 126-129.

Tombs, S., and D. Whyte (2015), The corporate criminal: why corporations must be abolished. Abingdon: Routledge.

Tombs, S. and D. Whyte (2007), Safety crimes. Cullompton, Willan.

Turner, T., C. Cross and M. O'Sullivan (2014), Does Union membership benefit immigrant workers in 'hard times'? Journal of Industrial Relations, no. 56(5), 611-630.

Van Duyne, P.C., and M.J. Houtzager (2005), 'Criminal sub-contracting in the Netherlands: the Dutch 'koppelbaas' as crime-entrepeneur'. In The Organised Crime Economy: Managing Crime Markets in Europe. Ed. by P.C. van Duyne, K. von Lampe, M. van Dijck and J.L. Newell. Nijmegen: Wolf Legal Publishers, pp.163-188.

van Erp, J., W. Huisman and G. Vande Walle, The routledge handbook of white-collar and corporate crime in Europe. London: Routledge, 2015.

Weil, D., 'A strategic approach to labour inspection'. International Labour Review 147(4), 349-375, 2008.

White, R., and J. Yeates, 'Farming and climate change'. In A Handbook of Food Crime. Ed. by Gray, A., and R. Hinch. Bristol: Bristol University Press, pp.315-330, 2018. 